\title{
Pengendalian penyakit hawar (lateblight) pada kentang (Solanum tuberosum 1.) melalui penerapan solarisasi tanah dan aplikasi agen hayati Trichoderma harzianum
}

\section{(Control of lateblight disease on potato by application of soil solarization and biological agent Trichoderma harzianum)}

\author{
E. Brugman, E. D. Purbajanti, dan E. Fuskhah \\ Agroecotechnology, Faculty of Animal and Agricultural Sciences, Diponegoro University \\ Tembalang Campus, Semarang 50275 - Indonesia \\ Corresponding E-mail: Eirenebrugman@gmail.com
}

\begin{abstract}
The purpose of the research was to assess the effectiveness of soil solarization and biological agent Trichoderma harzianum application in controlling lateblight disease caused by Phytophthora infestans on potato. The experiment was assigned in a split plot design with soil solarization as main plot and the density of Trichoderma harzianum as sub-plot. Soil solarization treatment consisted of solarization (A1) and non-solarization (A1). Density of Trichoderma harzianum used was B1(control) $=0 \mathrm{~g}, \mathrm{~B} 2=10 \mathrm{~g}\left(10^{7}\right.$ $\mathrm{cfu} / \mathrm{l}), \mathrm{B} 3=20 \mathrm{~g}\left(2 \times 10^{8} \mathrm{cfu} / \mathrm{l}\right), \mathrm{B} 4=30 \mathrm{~g}\left(3 \times 10^{8} \mathrm{cfu} / \mathrm{l}\right)$ and B5 $=40 \mathrm{~g}\left(4 \times 10^{8} \mathrm{cfu} / \mathrm{l}\right)$. Soil solarization treatment was carried out by using transparent polyethylene sheets with a thickness of $45 \mu \mathrm{m}$. Parameters measured were soil temperature, intensity level of pathogen attack, the rate of infection and total yield. Data were subjected to ANOVA and followed by LSD test. Soil solarization for 4 weeks increase the soil temperature by $7.6^{\circ} \mathrm{C}$ and significantly increase the production of potato by $14.28 \%$. Application of biological agent Trichoderma harzianum on level B4 30g (3 x $108 \mathrm{cfu} / \mathrm{L})$ gives the best results in reducing the the intensity level of pathogen attack by $87.61 \%$ and the rate of disease infection into 0.044 unit/day. The results of this research may provide benefical information in the future for plant protection activities.
\end{abstract}

Keywords : P.infestans, Trichoderma harzianum, soil solarization, potato

\begin{abstract}
ABSTRAK
Penelitian ini bertujuan untuk mengkaji efektivitas solarisasi tanah dan aplikasi agen hayati Trichoderma harzianum dalam mengendalikan penyakit hawar yang di sebabkan oleh Phytophthora infestans pada tanaman kentang. Penelitian menggunakan rancangan petak terbagi dengan petak utama adalah perlakuan solarisasi dan anak petak dosis Trichoderma harzianum. Perlakuan solarisasi tanah terdiri dari solarisasi dan non-solarisasi. Dosis Trichoderma harzianum yang digunakan terdiri dari $\mathrm{B} 1(\mathrm{kontrol})=0 \mathrm{~g}, \mathrm{~B} 2=10 \mathrm{~g}\left(10^{7} \mathrm{cfu} / \mathrm{l}\right), \mathrm{B}_{3}=20 \mathrm{~g}\left(2 \times 10^{8} \mathrm{cfu} / \mathrm{l}\right), \mathrm{B}_{4}=30 \mathrm{~g}\left(3 \times 10^{8} \mathrm{cfu} / 1\right)$ dan $\mathrm{B}_{5}=40 \mathrm{~g}(4$ x $\left.10^{8} \mathrm{cfu} / \mathrm{l}\right)$. Perlakuan di ulang sebanyak 3 kali. Solarisasi tanah dilakukan dengan menggunakan plastik polietilen transparan ukuran $45 \mu \mathrm{m}$. Parameter yang diamati adalah suhu tanah, intensitas serangan patogen, laju infeksi penyakit dan produksi tanaman kentang. Data dianalisis ragam dan dilanjutkan dengan uji Beda Nyata Terkecil Solarisasi tanah selama 4 minggu meningkatkan suhu tanah sebesar $7,6^{\circ} \mathrm{C}$ dan secara nyata dapat meningkatkan produksi tanaman kentang sebesar $14,28 \%$. Pemberian agen hayati Trichoderma harzianum pada tingkat $\mathrm{B}_{4} 30 \mathrm{~g}\left(3 \times 10^{8} \mathrm{cfu} / \mathrm{L}\right)$ memberikan hasil terbaik dalam menekan tingkat intensitas serangan patogen Phytophthora infestans sebesar 87,61\% dan laju penyakit menjadi 0,044 unit/hari.

Kata kunci: P. infestans, Trichoderma harzianum, solarisasi tanah, kentang
\end{abstract}




\section{PENDAHULUAN}

Tanaman kentang (Solanum tuberosum L) merupakan komoditas holtikultura yang memiliki potensi sebagai bahan pengganti pangan pokok. Kentang merupakan salah satu komoditas pilihan untuk mendukung program diversifikasi dalam rangka mewujudkan ketahanan pangan berkelanjutan (IPC, 2008). Produksi kentang nasional pada tahun 2014 adalah 1.347.815 ton dengan produktivitas sebesar 17,67 ton/ha (BPS, 2015). Produktivitas tersebut masih jauh lebih rendah dibandingkan dengan potensi produksi kentang yang mencapai 25 ton/ha (IPC, 2008). Upaya peningkatan produksi kentang tidak terlepas dari kegiatan pengendalian hama dan penyakit kentang.

Tanaman kentang merupakan tanaman yang mempunyai hama penyakit terbanyak. Tanaman kentang mempunyai 266 hama dan penyakit yang terdiri dari 23 virus, 38 cendawan, 6 bakteri, 2 mikoplasma, 1 viroid, 68 nematoda dan 128 insekta (Sastrahidayat, 2011). Salah satu penyakit utama kentang di Indonesia adalah penyakit hawar (lateblight) yang disebabkan oleh Phytophthora infestans. Patogen ini menyebabkan bercak luka dan busuk pada jaringan tanaman yang diinfeksinya dan mengakibatkan kehilangan hasil antara $10-100 \%$ tergantung pada tingkat infestasi, musim, ketinggian, dan varietas kentang (Nathasia et al., 2014). Zoospore dari Phytophora infestans tidak dapat mensintesis sterol yang merupakan target dari banyak fungisida sehingga sulit dikendalikan dengan fungisida (Gaulin et al., 2010).

Solarisasi tanah merupakan teknik yang digunakan untuk menutupi permukaan tanah dengan lembaran polietilen transparan selama musim panas, untuk menangkap radiasi matahari agar menaikkan suhu tanah (Candido et al., 2011). Beberapa penelitian terdahulu menyimpulkan bahwa solarisasi tanah dapat menekan pertumbuhan patogen tular tanah seperti Sclerotium rolfsii (Kartini dan Widodo, 2000), Armillaria sp. (Otieno et al., 2003), Fusarium sp. (Shofiyani dan Budi, 2014), dan Sclerotium cepivorum (Melero-vala et al., 2000) serta menurunkan kejadian penyakit busuk akar teh (Otieno et al., 2003) dan busuk umbi bawang (Carrieri et al., 2013). Efek solarisasi tanah dalam menekan beberapa penyakit tumbuhan juga berkontribusi meningkatkan kerja dari agen antagonis seperti Trichoderma.

Trichoderma harzianum termasuk dalam golongan cendawan askomisetik yang bersifat antagonis terhadap phytopatogen (RomaoDumareq et al., 2012). Trichoderma bekerja melawan patogen secara langsung dengan cara mikoparasitisme, memproduksi enzim pemecah dinding sel dan senyawa antimikroba, atau secara tidak langsung dengan kompetisi nutrisi dan tempat, memodifikasi lingkungan tumbuh dan meningkatkan pertumbuhan tanaman (Vos et al., 2015). Trichoderma harzianum memiliki kemampuan rekolonisasi yang cepat sehingga solarisasi tanah tidak terlalu berpengaruh terhadap populasinya (Poras et al., 2007).

Penelitian ini bertujuan untuk mengetahui efektifitas penerapan solarisasi tanah dan densitas yang efektif dari aplikasi Trichoderma harzianum dalam mengendalikan Pytophthora infestans, serta mengetahui interaksi antara solarisasi tanah dan aplikasi Trichoderma harzianum dalam pengendalian penyakit hawar kentang oleh Pytophthora infestans.

\section{Materi}

\section{MATERI DAN METODE}

Penelitian telah dilaksanakan pada tanggal 18 Oktober 2016 sampai dengan 07 Maret 2017 di Balai Benih Tanaman Pangan dan Hortikultura (BBTPH) Kopeng, Laboratorium Terpadu Undip, dan Laboratorium Ekologi dan Produksi Tanaman, Fakultas Peternakan dan Pertanian, Universitas Diponegoro. Materi yang digunakan antara lain benih kentang varietas granola (G2) sebanyak 60 knol, media tanam tanah steril sebanyak $12 \mathrm{~kg}$ per pot percobaan, inokulum trichoderma harzianum sebanyak $600 \mathrm{~g}$ dengan kepadatan $10^{7} \mathrm{cfu} / \mathrm{g}$, isolat murni patogen phytophthora infestans dengan kepadatan $10^{5}-10^{6} \mathrm{cfu} / \mathrm{ml}$, media kultur PDA, Basamid-G sebagai bahan sterilisasi tanah dan pupuk urea $225 \mathrm{~kg} / \mathrm{ha}, \mathrm{ZA} 150 \mathrm{~kg} / \mathrm{ha}, \mathrm{KCl} 150$ $\mathrm{kg} / \mathrm{ha}$, dan TSP $300 \mathrm{~kg} / \mathrm{ha}$.

\section{Metode}

Penelitian dilaksanakan dengan menyiapkan media tanah yang kemudian disterilisasi secara kimia menggunakan Basamid-G. Pemberian isolat dilakukan dengan menginfeksi tanah yang telah 
disterilisasi dengan isolat patogen Phytophthora infestans sebanyak $5 \mathrm{ml}$ untuk setiap pot percobaan dan diikuti dengan pemberian inokulum Trichoderma harzianum 3 hari selanjutnya sesuai dengan dosis perlakuan. Tahap solarisasi dilakukan satu minggu setelah pemberian inokulum trichoderma dan dilakukan selama 4 minggu. Solarisasi tanah dilakukan dengan menutup pot percobaan dengan menggunakan lembaran polietilen bening yang ujung-ujungnya ditutup rapat. Pot percobaan di letakkan pada tempat yang mendapat matahari penuh sepanjang hari. Penanaman bibit tanaman kentang dilakukan saat perlakuan solarisasi telah selesai. Lembaran polietilen bening dilepaskan lalu pada setiap pot percobaan di tanam dua bibit kentang. Pemeliharaan berupa penyiraman dan pemupukan menggunakan Urea $225 \mathrm{~kg} / \mathrm{ha}$, ZA $150 \mathrm{~kg} / \mathrm{ha}, \mathrm{KCl}$ $150 \mathrm{~kg} / \mathrm{ha}$, dan TSP $300 \mathrm{~kg} / \mathrm{ha}$.

Parameter yang diamati antara lain adalah 1) Suhu tanah, 2) Intensitas Serangan Patogen, 3) Laju Infeksi Penyakit dan 4) Produksi tanaman. Pengamatan serangan penyakit dilakukan pada saat kentang berumur 30 hst, 35 hst, 40 hst, 45 hst, 50 hst, 55 hst, 60 hst dan saat panen. Perhitungan intensitas serangan (X) dilakukan pada $45 \mathrm{hst}$ dengan perhitungan langsung menurut Sastrahidayat dan Djauhari (2014) sebagai berikut:

$$
I=\frac{\sum(n \cdot v)}{N \cdot Z} \times 100
$$

Keterangan:

$$
\begin{aligned}
& \mathrm{I} \quad \text { Intensitas serangan } \\
& \mathrm{Z} \quad \text { = Nilai skala dari kategori serangan tertinggi } \\
& \mathrm{N} \quad \text { Banyaknya daun yang diamati } \\
& \mathrm{n} \quad \text { = Jumlah daun tanaman pada setiap kategori } \\
& \text { serangan } \\
& \mathrm{v} \quad \begin{array}{l}
\text { = Nilai skala dari setiap kategori } \\
\quad \text { serangan }
\end{array}
\end{aligned}
$$

Perhitungan laju infeksi penyakit dihitung berdasarkan perkembangan penyakit (Oka, 1993) menggunakan formula berikut:

$$
r=\frac{2,3}{t}\left(\log \frac{X 1}{1-X 1}-\log \frac{X 0}{1-X 0}\right)
$$

Keterangan: $\mathrm{r} \quad=$ laju infeksi $\left(\right.$ UnitWaktu $\left.^{-1}\right)$

2,3 = bilangan hasil konversi log alami

logaritma biasa

$\mathrm{t}=$ selang waktu pengamatan

$\mathrm{X} 0=$ proporsi penyakit hawar pada

pengamatan pertama

$\mathrm{X} 1$ = proporsi penyakit hawar pada

pengamatan berikut

\section{Rancangan Percobaan dan Analisis Data}

Rancangan yang digunakan dalam penelitian ini adalah Rancangan Petak Terbagi dengan rancangan dasar Rancangan Acak Kelompok . Petak utama adalah solarisasi tanah $\left(\mathrm{A}_{1}=\right.$ solarisasi, $\mathrm{A}_{2}=$ non-solarisasi) dan anak petak adalah aplikasi trichoderma pada empat taraf dosis $\mathrm{B}_{1}=0 \mathrm{~g}, \mathrm{~B} 2=10 \mathrm{~g}\left(10^{7} \mathrm{cfu} / \mathrm{l}\right), \mathrm{B}_{3}=20 \mathrm{~g}(2 \mathrm{x}$ $\left.10^{7} \mathrm{cfu} / \mathrm{l}\right), \mathrm{B}_{4}=30 \mathrm{~g}\left(3 \times 10^{7} \mathrm{cfu} / \mathrm{l}\right)$ dan $\mathrm{B}_{5}=40 \mathrm{~g}(4$ $\left.\times 10^{7} \mathrm{cfu} / \mathrm{l}\right)$ untuk setiap $12 \mathrm{~kg}$ tanah. Pengulangan dilakukan sebanyak 3 kali membentuk 30 unit percobaan. Analisis data dilakukan dengan menggunakan Analisis Ragam dan jika terdapat perbedaan akan dilanjutkan dengan uji LSD (Least Significant Difference) pada taraf $\alpha=5 \%$. Data yang tidak homogen ditransformasi kedalam bentuk akar kuadrat dan arcsin sebelum dianalisis ragam.

\section{HASIL DAN PEMBAHASAN}

\section{Suhu Tanah}

Berdasarkan data klimatologi BBTPH Kopeng, selama perlakuan curah hujan rata-rata adalah $15,08 \mathrm{~mm} /$ hari, suhu udara rata-rata $18^{\circ} \mathrm{C}$ dan kelembapan udara rata-rata 95\%. Hasil pengamatan perubahan suhu tanah selama perlakuan solarisasi tanah disajikan pada Ilustrasi 1.

Grafik perubahan suhu pada Ilustrasi 1 menunjukkan bahwa suhu tanah pada perlakuan solarisasi lebih tinggi dibanding dengan perlakuan non solarisasi dan memiliki tren yang cenderung meningkat. Perbedaan suhu tanah tertinggi dalam penelitian ini diperoleh pada minggu keempat dimana suhu tanah pada perlakuan solarisasi tanah lebih besar $7,6^{\circ} \mathrm{C}$ atau $30,76 \%$ dibanding dengan perlakuan non solarisasi. Hasil tersebut sesuai dengan beberapa penelitian solarisasi sebelumnya 


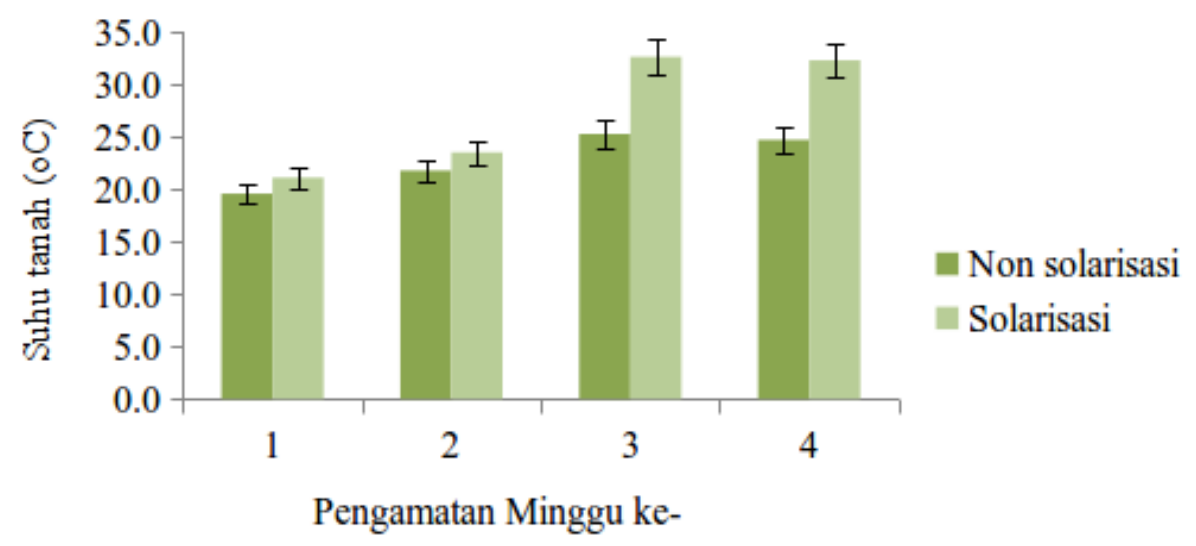

Ilustrasi 1. Perubahan suhu tanah selama perlakuan solarisasi

(Candido et al., 2011; Culman et al., 2006) yang menyimpulkan bahwa solarisasi tanah meningkatkan suhu sebesar $22 \%$ dan dapat mencapai suhu $40,5{ }^{\circ} \mathrm{C}$ pada kedalaman tanah 5 $\mathrm{cm}$. Solarisasi tanah bekerja dengan menyerap radiasi gelombang pendek dan meneruskan radiasi gelombang panjang. Radiasi gelombang pendek tersebut kemudian akan meningkatkan aliran panas ketanah (Katan dan DeVay, 1991).

\section{Intensitas Serangan Patogen}

Intensitas Serangan Patogen merupakan presentase luasnya jaringan tanaman yang terserang oleh patogen dari total luasan yang diamati. Pengukuran ISP bertujuan untuk megetahui tingkat keparahan penyakit tanaman. Data hasil pengamatan ISP dari masing-masing perlakuan disajikan pada Tabel 1.

Hasil pengamatan ISP pada Tabel 1 menunjukkan bahwa tidak ada interaksi dari perlakuan solarisasi tanah dan dosis Trichoderma harzianum terhadap intensitas serangan patogen. Perlakuan solarisasi tanah tidak memberikan pengaruh nyata terhadap intensitas serangan patogen. Intensitas serangan patogen pada perlakuan solarisasi adalah $14,32 \%$ dan perlakuan non solarisasi adalah $16,99 \%$. Tidak adanya pengaruh dari solarisasi tanah disebabkan tidak optimalnya kenaikan suhu tanah pada perlakuan

Tabel 1. Intensitas Serangan Patogen pada Tanaman Kentang 45 HST

\begin{tabular}{|c|c|c|c|}
\hline \multirow{2}{*}{ Dosis Trichoderma } & \multicolumn{2}{|c|}{ IIntensitas Serangan Patogen (ISP) } & \multirow{2}{*}{ Rerata } \\
\hline & Solarisasi & Non-solarisasi & \\
\hline ........(g).......... & \multicolumn{3}{|c|}{ 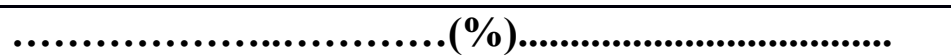 } \\
\hline $\mathrm{B} 1\left(0 / 1000 \mathrm{~cm}^{3}\right)$ & 27,11 & 28,10 & $27,61^{\mathrm{a}}$ \\
\hline $\mathrm{B} 2\left(10 / 1000 \mathrm{~cm}^{3}\right)$ & 22,72 & 28,14 & $25,43^{\mathrm{a}}$ \\
\hline B3 $\left(20 / 1000 \mathrm{~cm}^{3}\right.$ & 10,88 & 18,83 & $14,85^{\mathrm{b}}$ \\
\hline $\mathrm{B} 4\left(30 / 1000 \mathrm{~cm}^{3}\right)$ & 3,22 & 3,63 & $3,42^{\mathrm{b}}$ \\
\hline B5 $\left(40 / 1000 \mathrm{~cm}^{3}\right)$ & 7,65 & 6,25 & $9,95^{\mathrm{b}}$ \\
\hline Rerata & $14,32^{\mathrm{a}}$ & $16,99^{\mathrm{a}}$ & \\
\hline
\end{tabular}

Superskrip berbeda pada kolom yang sama menunjukkan perbedaan nyata $(\mathrm{P}<0,05)$. 
solarisasi tanah dimana suhu tertinggi dari perlakuan solarisasi adalah $34^{\circ} \mathrm{C}$ dan perlakuan non solarisasi adalah $27^{\circ} \mathrm{C}$, suhu tersebut tidak cukup untuk mematikan dan menekan populasi dari patogen Phytophthora infestans. Phytophthora infestans dapat hidup pada kisaran suhu $12-24^{\circ} \mathrm{C}$ dan termasuk dalam kategori cendawan mesofilik (Sastrahidayat, 2011). Suhu yang dibutuhkan untuk mematikan (ED90) cendawan mesofilik adalah pada kisaran $37^{\circ} \mathrm{C}$ selama 2 - 4 minggu atau $47^{\circ} \mathrm{C}$ selama 1 - 6 jam (Kartini dan Widodo, 2000).

Perlakuan aplikasi agen hayati Trichoderma harzianum memberikan pengaruh nyata terhadap intensitas serangan patogen. Pemberian Trichoderma harzianum dapat menurunkan intensitas serangan patogen Phytophthora infestans sebesar $87,61 \%$. Trichoderma bekerja melawan patogen secara langsung dengan cara mikoparasitisme, memproduksi enzim pemecah dinding sel dan senyawa antimikroba, atau secara tidak langsung dengan kompetisi nutrisi dan tempat, memodifikasi lingkungan tumbuh dan meningkatkan pertumbuhan tanaman (Vos et al., 2015). Trichoderma melakukan parasitisme dengan melakukan penetrasi langsung ke dinding sel patogen atau pada hifa patogen untuk mengambil isinya (Purnomo, 2010). Uji dual kultur Trichoderma dengan patogen Sclerotinia sclerotium sebelumnya menunjukkan bahwa hifa dari Trichoderma tumbuh membelit dan menghasilkan cabang yang melekat pada hifa Sclerotinia sclerotium sehingga menghambat pertumbuhan Sclerotinia sclerotium sebesar 56,3\%
(Zhang et al., 2016).

Tingkat intensitas serangan patogen terendah diperoleh pada perlakuan dosis Trichoderma B4 $\left(30 \mathrm{~g} / 1000 \mathrm{~cm}^{3}\right)$ dan B5 $\left(40 \mathrm{~g} / 1000 \mathrm{~cm}^{3)}\right.$ dengan tingkat intensitas serangan patogen berturut-turut $3,42 \%$ dan $6,95 \%$. Kepadatan populasi Trichoderma yang bekerja secara antagonis terhadap phytopathogen akan mempengaruhi aktivitas dari Phytophthora infestans. Hasil penelitian tersebut sesuai dengan penelitian terdahulu yang menyimpulkan bahwa perlakuan dengan tingkat kepadatan tertinggi yaitu $10^{8}$ dan $10^{10} \mathrm{spora} / \mathrm{g}$ tanah memberikan hasil terbaik dalam menekan jumlah telur nematode (Al-Hazmi dan Tariqjaveed, 2016). Pada uji invitro Trichoderma harzianum terbukti menunjukkan aktivitas antagonisme yang tinggi terhadap phytopathogen dengan menghambat pertumbuhannya hingga $100 \%$ (Bae et al., 2016).

\section{Laju Infeksi Penyakit}

Laju infeksi (r) adalah suatu angka yang menunjukkan seberapa cepat populasi patogen berkembang atau yang menunjukkan perkembangan populasi patogen per unit per satuan waktu. Data hasil analisis laju infeksi penyakit pada tanaman kentang umur 45 - 55 HST dari masing-masing perlakuan disajikan pada Tabel 2.

Data laju infeksi penyakit pada Tabel 2 menunjukkan bahwa kombinasi perlakuan solarisasi dan dosis Trichoderma harzianum tidak memili interaksi nyata. Perlakuan tunggal dosis

Tabel 2. Laju infeksi penyakit akibat perlakuan solarisasi tanah dan pemberian Trichoderma harzianum

\begin{tabular}{|c|c|c|c|}
\hline \multirow{2}{*}{ Dosis Trichoderma } & \multicolumn{2}{|c|}{ Laju Infeksi Penyakit } & \multirow{2}{*}{ Rerata } \\
\hline & Solarisasi & Non-solarisasi & \\
\hline ........(g). & \multicolumn{3}{|c|}{........................(unit/hari)................................ } \\
\hline $\mathrm{B} 1\left(0 / 1000 \mathrm{~cm}^{3}\right)$ & 0,113 & 0,124 & $0,118^{\mathrm{a}}$ \\
\hline $\mathrm{B} 2\left(10 / 1000 \mathrm{~cm}^{3}\right)$ & 0,198 & 0,113 & $0,155^{\mathrm{ab}}$ \\
\hline B3 $\left(20 / 1000 \mathrm{~cm}^{3}\right)$ & 0,025 & 0,109 & $0,067^{\mathrm{b}}$ \\
\hline $\mathrm{B} 4\left(30 / 1000 \mathrm{~cm}^{3}\right)$ & 0,036 & 0,053 & $0,044^{\mathrm{b}}$ \\
\hline $\mathrm{B} 5\left(40 / 1000 \mathrm{~cm}^{3}\right)$ & 0,034 & 0,074 & $0,054^{\mathrm{b}}$ \\
\hline Rerata & $0,081^{\mathrm{a}}$ & $0,087^{\mathrm{a}}$ & \\
\hline
\end{tabular}

Superskrip berbeda pada kolom yang sama menunjukkan perbedaan nyata $(\mathrm{P}<0,05)$. 
Trichoderma harzianum memiliki pengaruh nyata terhadap laju infeksi. Perlakuan B3 (20 g/1000 $\left.\mathrm{cm}^{3}\right)$, B4 $\left(30 \mathrm{~g} / 1000 \mathrm{~cm}^{3}\right)$ dan B5 $\left(40 \mathrm{~g} / 1000 \mathrm{~cm}^{3}\right)$ memiliki laju infeksi berturut-turut 0,067 unit/hari, 0,044 unit/hari dan 0,054 unit/hari. Laju infeksi pada tanaman merupakan jumlah pertambahan infeksi per satuan waktu. Infeksi tersebut dinyatakan dengan kerusakan pada satu tanaman atau bagian tanaman baik lokal maupun sistemik (Nirwanto, 2007). Pengaruh penurunan laju infeksi oleh perlakuan Trichoderma harzianum diakibatkan oleh aktivitas antagonisme yang dilakukan oleh Trichoderma harzianum. Trichoderma harzianum bekerja melawan patogen secara langsung dengan cara mikoparasitisme, memproduksi enzim pemecah dinding sel dan senyawa antimikroba, atau secara tidak langsung dengan kompetisi nutrisi dan tempat, memodifikasi lingkungan tumbuh dan meningkatkan pertumbuhan tanaman (Vos et al., 2015). Senyawa antimikroba yang diproduksi oleh Trichoderma berfungsi sebagai inhibitor dari phytopathogen yang dapat menekan aktivitas dari patogen (Vinale dkk, 2008). Trichoderma harzianum merupakan cendawan antagonis dengan kemampuan rekolonisasi yang cepat sehingga solarisasi tanah tidak terlalu berpengaruh terhadap populasinya (Poras et al., 2007).

\section{Produksi Tanaman}

Hasil analisis pengaruh solarisasi tanah dan Trichoderma harzianum terhadap produksi tanaman kentang disajikan pada Tabel 3.
Data produksi tanaman pada Tabel 3 menunjukkan bahwa tidak ada interaksi dari perlakuan solarisasi dan dosis Trichoderma terhadap produksi tanaman. Perlakuan dosis Trichoderma tidak berpengaruh nyata terhadap produksi tanaman. Trichoderma merupakan agen hayati yang bekerja melawan patogen baik secara langsung maupun tidak langsung. Tidak adanya pengaruh dari perlakuan Trichoderma terhadap produksi tanaman dimungkinkan karena aktivitas dari Trichoderma tidak memiliki pengaruh langsung terhadap produksi tanaman. Aktivitas antagonisme dari Trichoderma diharapkan dapat menurunkan tingkat serangan patogen yang nantinya dapat memaksimalkan potensi produksi dari tanaman.

Hasil pengamatan pada tabel 3 menunjukkan bahwa perlakuan solarisasi tanah berpengaruh nyata terhadap produksi tanaman. Rataan produksi tanaman pada perlakuan solarisasi tanah terbukti lebih tinggi dari perlakuan non solarisasi. Pada perlakuan solarisasi rataan produksi adalah 208 $\mathrm{g} /$ pot $(12,75$ ton/ha) sedangkan pada perlakuan non solarisasi adalah $182 \mathrm{~g} /$ pot $(11,45 \mathrm{ton} / \mathrm{ha})$. Perlakuan solarisasi dapat meningkatkan produksi sebesar $14,88 \%$. Hal ini sesuai dengan penelitian terdahulu mengenai solarisasi yang menyimpulkan bahwa solarisasi tanah dapat meningkatkan produksi paprika baik kualitas maupun kuantitas (Zayed et al., 2013), meningkatkan jumlah tanaman dan berat kering selada (Candido et al., 2011) dan meningkatkan produksi stroberi sebesar 17,6\% (Porras et al., 2006). Solarisasi tanah mempengaruhi komposisi faktor biotik, struktur

Tabel 3. Produksi Kentang akibat Perlakuan Solarisasi Tanah dan Pemberian Trichoderma harzianum

\begin{tabular}{|c|c|c|c|}
\hline \multirow{2}{*}{ Dosis Trichoderma } & \multicolumn{2}{|c|}{ Produksi } & \multirow{2}{*}{ Rerata } \\
\hline & Solarisasi & Non-solarisasi & \\
\hline ........(g)......... & \multicolumn{2}{|c|}{ f.......................(g/pot)............................. } & \\
\hline $\mathrm{B} 1\left(0 / 1000 \mathrm{~cm}^{3}\right)$ & 173,33 & 146,67 & $160,00^{\mathrm{a}}$ \\
\hline $\mathrm{B} 2\left(10 / 1000 \mathrm{~cm}^{3}\right)$ & 186,67 & 170,00 & $178,33^{\mathrm{a}}$ \\
\hline B3 $\left(20 / 1000 \mathrm{~cm}^{3}\right.$ & 206,67 & 203,33 & $188,33^{\mathrm{a}}$ \\
\hline $\mathrm{B} 4\left(30 / 1000 \mathrm{~cm}^{3}\right)$ & 250,00 & 196,67 & $205,00^{\mathrm{a}}$ \\
\hline $\mathrm{B} 5\left(40 / 1000 \mathrm{~cm}^{3}\right)$ & 223,33 & 193,33 & $208,33^{\mathrm{a}}$ \\
\hline Rerata & $208,00^{\mathrm{a}}$ & $182,00^{\mathrm{b}}$ & \\
\hline
\end{tabular}


tanah dan senyawa-senyawa mineral yang tersedia bagi tanaman (Shofiyani dan Budi, 2014). Pelepasan nutrisi tanah akibat rangsangan panas yang merupakan efek samping dari solarisasi dilaporkan dapat memacu pertumbuhan tanaman (Stapleton dan Devay, 1995). Peningkatan produksi tanaman oleh solarisasi tanah dilaporkan juga berkaitan dengan perubahan fisiologi tanaman seperti peningkatan aktivitas fotosintesis, percepatan perkembangan jaringan dan penundaan senesens yang terjadi pada masa akhir perkembangan tanaman yang ditanaman di tanah solarisasi (Gruenzweig et al., 1993).

\section{KESIMPULAN}

Hasil penelitian menunjukkan bahwa perlakuan solarisasi tanah dapat meningkatkan suhu tanah sebesar 30,76\% dan dapat produksi tanaman kentang sebesar 14,28\% dibanding produksi non-solarisasi. Dosis terbaik Trichoderma untuk menurunkan intensitas serangan patogen dan laju penyakit adalah $30 \mathrm{~g} / 1000 \mathrm{~cm}^{3}$ (3 x $\left.10^{8} \mathrm{cfu} / \mathrm{l}\right)$. Tidak ada interaksi dari perlakuan solarisasi dan kepadatan Trichoderma terhadap semua parameter yang diamati.

\section{DAFTAR PUSTAKA}

Al-Hazmi, A.S. dan M. TariqJaveed. 2016. Effects of different inoculum densities of Trichoderma harzianum ant Trichoderma viridae againts Meloidogyne javanica on Tomato. Saudi Journal of Biological Sciences. 23 : 288-292.

Barnett, H.L. dan B.B. Hunter. 1998. Illustrated Genera of Imperfect Fungi $4^{\text {th }}$ Edition. American Phytopathological Society Press, Minnesota.

Bae, S.J., T.K. Mohanta, J.Y. Chung, M. Ryu, G. Park, S. Shim, S. Hong, H. Seo, D.W. Bae, I. Bae, J. Kim dan H. Bae. 2016. Trichoderma metabolites as biological control agents against Phytophthora pathogens. Biological Control 92:128-138.

Candido, Vincenzo, D.A. Trifone, M. Vito, dan D. Castronuovo. 2011. Scientia horticulturae weed control and yield response of soil solarization with different plastic films in lettuce. Scientia Horticulturae. 130 (3): 491-97.

Carrieri, F., F. Raimo, A. Pentangelo, dan E. Lahoz. 2013. F.poliferatum and F. tricintum as casual agent of pink root of onion bulbs and the effect of soil solarization combined with compost amendment in cotrolling their infections in field. Crop Protection. 43 : 3137.

Culman, S.W., J.M. Duxbury, J.G. Lauren dan J.E. A Thies. 2006. Microbial community response to soil solarization in Nepal's rice wheat cropping system. Crop Protection. 38 : 3359-71.

Gasoni, Laura, K. Nancy, Y. Viviana, Kobayashi, B. Silvana, B. Viviana, dan G. Zumelzu. 2008. Effect of soil solarization and biocontrol agents on plant stand and yield ' Rdoba on table beet.Crop Protection 27: 337-42.

Katan, J dan J.E. DeVay. 1991. Soil Solarization. CRC Press. London.

Kartini dan Widodo. 2000. Pengaruh solarisasi tanah terhadap pertumbuhan Sclerotium rolfsii SACC. dan patogenisitasnya pada kacang tanah. Buletin Hama dan Penyakit Tumbuhan. 12(2) : 53-59

Melero-Vara, J.M., A.M. Prados-Ligero, dan M.J. Basallote-Ureba 2000. Comparison of physical, chemical and biological methodsof controlling garlic white rot. J.Plant Pathology. 106 : 581-588.

Nathasia, A.A.V., Abadi, A.L., dan T. Wardiyati. 2014. Uji ketahanan 7 klon tanaman kentang terhadap penyakit hawar daun (Phytopthora infestans (Mont.) de Barry). Jurnal Produksi Tanaman. 1 (6) : 540-548

Nirwanto, H. 2007. Pengantar Epidemi dan Manajemen Penyakit Tanaman. UPN Veteran jawa Timur. Surabaya. 
Oka, IY. 1993. Pengantar Epidemiologi Penyakit Tanaman. Gajah Mada University Press. Yogyakarta.

Otieno, Washington, T. Aad, J. Mike, and C.O. Othieno. 2003. Efficacy of soil solarization, Trichoderma harzianum, and coffee pulp amendment against Armillaria Sp.. 22: 32531 .

Purnomo, H. 2010. Pengantar Pengendalian Hayati. ANDI, Yogyakarta.

Porras, M. Ã., C. Barrau, dan F. Romero. 2007. Effects of soil solarization and trichoderma on strawberry production. Crop Protection. 26: $782-87$.

Romao-Dumareq, A.S., N.J. Talbolt, dan C.R. Thornton. 2012. RNA interference of endochitinases in the sugarcanes endophyte Trichoderma virens 223 reduces its fitness as a biocontrol agent of pineapple disease. PloS One 7, e47888

Sastrahidayat, I. R., dan S. Djauhari. 2014. Teknik Penelitian Fitopatologi. Universitas Brawijaya Press. Malang.

Sastrahidayat, I.R. 2011. Tanaman Kentang dan Pengendalian Penyakitnya. UB Press, Malang.

Shofiyani, A. dan G.P. Budi. 2014. Efektifitas solarisasi tanah terhadap penekanan perkembangan jamur fusarium ada lahan tanaman pisang yang terinfeksi. Prosiding Seminar Nasional Hasil-hasil penleitian dan Pengabdian LPPM UMP 2014

Soesanto, L., E. Mugiastuti, dan R.F. Rahayuniati. 2011. Inventarisasi dan identifikasi patogen tular-tanah pada pertanaman kentang di Kabupaten Purbalingga. J. Hortikultura 21 (3) : 254-264
Stapleton, J.J. dan DeVay, J.E.1995. Soil Solarization: a Natural Mechanism of Integrated Pest Management. CRC Press, Boca Raton.XSuwandi, W.M., Pradjadinata D., Ruswandi, P., Leksono dan M. Nobuo. 2001. Visualisasi gejala infeksi penyakit dan hama pada tanaman dan ubi kentang varietas granola. BPSB-TPH. Jawa Barat.

Vinale, F., K. Sivasithamparam, L. Ghisalberti, R. Marra, dan M. Lorito. 2008. Trichodermaplant pathogen interactions. Soil Biol. Bhiochemical. $40: 1-10$.

Vos, C.M.F., De Cremer, K., Cammue, B.P.A., dan B. Connick. 2015. The toolbox of Trichoderma spp. in the biocontrol of botrys cinerea disease. Mol. Plant Pathology 16 : $400-412$.

www.bps.go.id (diakses pada 16 April 2016)

Youssef, S.A., A.K. Tartoura, dan G.A. Abdelraouf. 2016. Evaluation of Trichoderma harzianum and Serratia proteamaculans effect on disease suppression, stimulation of ROSscavenging enzymes and improving tomato growth infected by Rhizoctonia solani. Biological Control. 100 :79-86.

Zhang, F., H. Ge, F. Zhang, N. Guo, Y. Wang, L. Chen, X. Ji dan C. Li. 2016. Biocontrol Potential of Trichoderma harzianum isolate T-aloe against Sclerotinia sclerotiorum in soybean. Plant Physiology and Biochemistry. 100: 64-74.

Zayed, M. S. 2013. Productivity of pepper crop (Capsicum Annuum L.) as affected by organic fertilizer, soil solarization, and endomycorrhizae. Annals of Agricultural Sciences 58 (2) : $131-137$ 